\title{
Kapital Politik: Kuasa yang Mengikat dalam Relasi Kerja Nelayan dan Pangamba' di Pondok Mimbo
}

\section{Adhe Yoga Rivaldi}

Program Studi Sosiologi Fakultas Ilmu Sosial dan Ilmu Politik Universitas Jember

Email: adhe.yr151@gmail.com

\begin{abstract}
Abstrak
Artikel ini membahas tentang tindakan kuasa atau penggunaan kekuasaan dalam relasi kerja nelayan dan pangamba' di Pondok Mimbo. Keterikatan terjadi ketika nelayan membangun kerja sama dan menyepakati kontrak kerja dengan pangamba', tselama kontrak belum selesai maka nelayan harus memberikan hasil tangkapan ikan kepada pangamba' sebelum di jual ke pedagang yang kemudian dilakukan pembagian hasil sesuai kesepakatan kerja yaitu $10 \%$ hingga $20 \%$ untuk pangamba' dari hasil pendapatan nelayan. Tidak adanya batasan kontrak kerja menjadikan relasi tersebut begitu mengikat, karena nelayan harus mematuhi sistim amba' atau norma yang berlaku. Alhasil, nelayan akan terus terikat dengan pangamba' namun, karena relasi tersebut untuk kebutuhan modal, mengharuskan nelayan untuk melunasinya kepada pangamba' agar dapat lepas dari kontrak kerja tersebut. Tujuan penelitian ini untuk mendeskripsikan dan menganalisis peran kapital politik dalam relasi nelayan dan pangamba'. Metode penelitian ini adalah kualitatif, didukung dengan melakukan observasi partisipan dan wawancara mendalam untuk mengumpulkan data. Hasil penelitian menunjukan adanya kekuasaan dalam relasi kerja nelayan dan pangamba', terutama pada sikap kepatuhan, bahkan menunjukan adanya persaingan kerja dalam relasi tersebut. Selanjurnya, penelitian juga menunjukkan bahwa masing-masing pihak melakukan kecurangan kerja demi keuntungan yang lebih, entah itu dari diri nelayan maupun pangamba'.
\end{abstract}

\section{Political Capital: Binding Power in The Relationship of Fishermen and Pangamba' Workers in Pondok Mimbo}

\begin{abstract}
This article discusses the role of power on the work relations of fishermen and the middle man at Pondok Mimbo. Engagement occurs when the fisherman builds a partnership and accept a work contract, as long as the contract has not been completed. The fisherman must provide the fish catch to the middle man before it is sold to the trader and then share the results according to the work agreement which is $10 \%$ to $20 \%$ for the middle man from the income of the fisherman. The absence of work contract restrictions makes the relationship so binding because fishermen must comply with the amba system 'or the prevailing norms. As a result, fishermen will continue to be bound to the middle man but, because the relationship is for capital needs, it requires fishermen to pay it to the middle man to be free from the employment contract. The purpose of this study is to describe and analyze the role of political capital in the relations of fishermen and the middle man. This research method is qualitative, supported by participant observation, and in-depth interviews to collect data. The results showed the existence of power in the work relations of fishermen and the middle man especially in the attitude of compliance, even showing the existence of work competition in the relationship. Further, each party is cheating work for more profit, whether it's from the fishermen themselves or the middle man.
\end{abstract}

Keywords : political capital, relationship, engagement, power, authority 


\section{PENDAHULUAN}

Modal menjadi hal yang terpenting bagi nelayan, karena modal merupakan aset terpenting untuk mendukung kebutuhan kerjanya seperti halnya uang. Namun, kebutuhan nelayan atau juragan darat bukan hanya semata untuk mencukupi kebutuhan hidup, melainkan juga untuk mencukupi kebutuhan kerjanya seperti halnya pembelian dan perawatan kapal, beserta alat-alat pendukung lainnya (jaring, lampu, dan mesin). Nampaknya, hasil observasi kebanyakan nelayan tidak mampu mencukupi kebutuhan kerjanya karena modal kerja yang dibutuhkan terlalu besar, sehingga memerlukan modal tambahan. Modal tersebut bisa didapat dari aktor lain yang dapat mendukung dan membantu dalam mencukupi modalnya.

Di Pondok Mimbo, nelayan (juragan darat) untuk memenuhi kebutuhan modalnya menjalin kerja sama dengan pangamba'. Pangamba' merupakan aktor yang siap menginvestasikan modalnya untuk para juragan darat (pemilik kapal). Namun, dalam menjalin relasi tersebut terdapat norma atau sistem amba'an yang harus dilaksanakan oleh nelayan, yaitu pertama selalu memberikan hasil tangkapnya kepada pangamba' terlebih dahulu untuk dijual kepada pedagang ikan dan baru dilakukan pembagian hasil. Kedua, pembagian hasil tersebut $10 \%$ (ketika juragan tidak membagikan ikan kepada ABK) atau 20\% (ketika juragan membagikan ikan kepada ABK) dari hasil tangkap nelayan untuk pangamba'. Ketiga harus melunasi atau membayar modal yang sudah diberikan dari pangamba' ketika berkeinginan berhenti atau memutus kontrak kerja, namun ketika nelayan tidak memiliki uang untuk membayar modal yang telah diberikan maka kontrak tidak akan putus hingga nelayan dapat melunasinya, sehingga posisi nelayan cukup sulit disatu sisi pendapatan yang tak tentu dan masih terikat oleh pangamba'.

Hal tersebut menunjukan bahwa, relasi yang terjadi antara nelayan dan pangamba' benar-benar mengikat. Meskipun begitu, nelayan dan pangamba' tidak begitu formal dalam melakukan kesepakatan kerja seperti halnya dengan lembaga koperasi ataupun bank, karena dalam peminjaman tersebut dilakukan dengan prosedur peminjaman yang tidak birokratis elitis,nan hirarkies serta pengembalian peminjaman yang relatif lama. Selain itu tidak ada angsuran rutin yang harus dibayarkan sehingga juragan darat dapat membayar hutangnya kapan saja selagi memiliki uang, bahkan tidak ada bungan, dan peminjaman dapat dilakukan setiap hari (Kusnadi, 2009: 51). Nampaknya, dalam melakukan peminjaman kepada pangamba' tidak menggunakan prosedur yang terlalu birokratis sehingga mempermudah nelayan (juragan darat) dalam mendapatkan modal. Namun, prosedur yang nampak indah tersebut hanya terjadi di awal karena ketika keterikatan itu terbangun antara nelayan dan pangamba' maka relasi tersebut akan mengikat dengan sendirinya. Bahkan ketika nelayan mengalami kerugian, gali lubang tutup lubang dengan melakukan peminjaman lagi untuk menutupnya tak bisa terelakkan. Alhasil, modal yang dipinjam hanya akan bertambah dan menjadi beban yang banyak bagi nelayan, sebab hal inilah menjadikan relasi tersebut mengikat tanpa ujung dan saling membutuhkan.

Artikel ini fokus pada peran kapital politik dalam relasi nelayan (juragan darat) dan pangamba'. Sebab, dengan melihat peran kapital politik, nantinya permasalahan tidak hanya akan menyinggung mengenai kuasa yang tertuju pada hubungan personal, namun juga meliputi elemen-elemen yang memiliki ikatan relasi yang saling membutuhkan dari adanya nelayan dan pangamba'. Bahkan permasalahan lainpun terkuak, sebagai contoh terjadi persaingan kerja dari nelayan dan pangamba' maupun dari pedagang, hingga munculnya tindakan merugikan dan kecurangan dalam relasi itu sendiri. Kapital politik akan menunjukan perannya dalam relasi tersebut, dan memposisikan kuasa dan wewenang kepada aktor atau individu yang lebih dominan dalam berkehendak melakukan tindakan yang bersinggungan dengan relasi nelayan dan pangamba' di Pondok Mimbo.

Kuasa dalam relasi nelayan dan pangamba' yang ada di Pondok Mimbo sebenarnya dapat menggambarkan dari peran 
kapital politik itu sendiri. Karena, kajian teoritis ini berpegangan dasar pada teori dan konsep milik Bourdieu (1986) mengenai kapital, khususnya kapital politik.

Dalam teorinya memiliki empat konsep penting yaitu status sosial, yang berhubungan langsung dengan stratifikasi sosial dan kelas sosial dalam masyarakat, khusunya dalam relasi nelayan dan pangamba' di Pondok Mimbo, sebab hal ini nantinya juga akan menunjukan kelas-kelas bagi individu yang dapat menunjukan posisi yang paling berkuasa dilingkupnya. Kemudian terkait dengan prestise sosial yang lebih memperlihatkan sikap gengsi yang dapat dimiliki individu terutama pada pangamba' terutama pada status sosialnya, yang akan bersaing untuk memperoleh sebanyak mungkin amba'an (nelayan yang memiliki ikatan kerja dengan pangamba') dan dapat memberikan posisi yang objektif dilingkungannya. Konsep ketiga yaitu otoritas, yang menunjukan adanya wewenang dan kekuasaan yang dimiliki individu dan dapat mempengaruhi orang lain, seperti halnya pangamba' yang menjadikan nelayan memiliki kepatuhan dengan memanfaatkan kuasanya sebagai penanam modal. Konsep terakhir yaiut simbol sosial. Simbol ini adalah tanda yang dapat menunjukan sikap atau maksud tertentu yang dilakukan oleh orang lain, namun dalam relasi kerja nelayan dan pangamba' simbol dimanfaatkan untuk mencari keuntungan yang lebih seperti melakukan kecurangan dengan memberikan kode dengan maksud tertentu kepada orang yang dituju, sehingga orang lain tidak akan mengerti simbol yang dilihat (Indrayani, 2019, p. 203). Sebab simbol tersebut terkadang dilakukan tanpa sepengetahuan orang lain.

Penelitian ini begitu penting karena, dapat memberikan gambaran dalam kehidupan masyarakat pesisir di Pondok Mimbo mengenai relasi kerja nelayan dan pangamba' berbasis modal politiknya. Harapannya, dalam penelitian selain bermanfaat bagi pembaca untuk mengetahui relasi nelayan dan pangamba' di Mimbo, juga lebih memahami mengenai peran dari kapital politik dalam relasi tersebut.
Sehingga, urgensi penelitian ini sebagai upaya pengembangan teori dan konsep kapital politik dalam kehidupan dan relasi sosial dalam masyarakat, serta menjelaskan mengenai penerapannya secara langsung di masyarakat pesisir, yakni pada kehidupan nelayan.

\section{METODE PENELITIAN}

Desain penelitian ini, menggunakan metode penelitian kualitatif yang digunakan untuk melihat kondisi secara alamiah di lapangan dengan memanfaatkan kedua mata secara langsung. Berkaitan dengan populasi dan sampel, peneliti menggunakan metode snowball sebagai cara peneliti memilih informan yang dipandang lebih mengerti dan jika informan sebelumnya belum dapat memberikan informasi yang seutuhnya, maka informan yang memiliki profesi yang sama dapat memberikan informasi yang lebih yang nantinya dapat melengkapi data penelitian ini. Tentunya, sasaran dalam penelitian ini adalah nelayan dan pangamba yang nantinya akan dijadikan sebagai informan atau narasumber sebagai pemberi data informasi yang akurat.

Pengumpulan data penelitian ini dilakukan dengan cara melakukan observasi partisipan Menurut, Susan Stain (1998) dalam (Sugiyono, 2018: 227), tahap observasi partisipatif bagi peneliti dilakukan dengan mengamati apa yang dikerjakan orang, mendengarkan apa yang mereka ucapkan, dan berpartisipasi dalam aktivitas mereka. Observasi yang dilakukan peneliti pada tanggal 23 April 2019 hingga 18 Februari 2020 untuk melihat keseharian atau aktivitas masyarakat pesisir Pondok Mimbo guna beradaptasi dan menggali data awal sebagai langkah untuk menunjang penelitian tahap selanjutnya. Kemudian, dalam wawancara medalam (in-depth interview) juga dilakukan untuk menggali data dari informan atau narasumber secara langsung dan mendalam. Tentunya, wawancara ini juga sudah dilakukan bersamaan dengan melakukan observasi tahap awal pada tanggal 23 April 2019, dalam wawancara tentu fokus informan adalah nelayan dan pangamba'. Dalam pengumpulan data juga didukung dengan cara mendokumentasikan data 
dilapangan sepertihalnya foto kegiatan nelayan dan pangamba', selebihnya juga merekam hasil wawancara secara langsung sebagai bukti hasil penelitian dilapangan.

Dalam menggunakan teknik analisis di penelitian ini, peneliti terlebih melakukan pengelompokan data sehingga nantinya dapat tersusun dengan rapi, dan memudahkan peneliti melakukan analisis data. Tentunya, didukung dengan teori kapital politik (status sosial, prestise sosial, otoritas, dan simbolik) milik Bourdieu yang nantinya juga akan digunakan sebagai dasar atau landasan teori sebagai acuan analisis pada pembahasan. Selebihnya, selama melakukan penelitian ini, informan yang berperan sangat membantu dan menjadi informan kunci adalah Bapak SND dan Ibu SS. Lokasi dalam penelitian ini berada di Dusun Pondok Mimbo, Desa Sumberanyar Kabupaten Situbondo, dan berlangsung selama terhitung sejak April 2019, kemudian dilanjut pada bulan Desember 2019 - Februari 2020.

Melakukan keabsahan data, peneliti melakukan perpanjangan pengamatan sebagai upaya untuk menambah data tambahan dan memastikan keakuratan data dengan informan satu dan yang lain, dan dikung dengan ketekukan dalam melakukan analisis dan pengelompokan data nantinya akan membantu dalam proses keabsahan. Triangulasi data juga dilakukan untuk membandingkan data dari informan satu dengan yang lain, sebagai upaya menyeimbangkan hasil informasi yang didapat dan memastikan kebenaran data itu sendiri. Selebihnya, menggunakan bahan referensi sepertihalnya data dari desa untuk memberikan data yang benar-benar akurat, beserta referensi penelitian sebagai penunjang penelitian dalam melakukan penulisan. Yang terakhir, melakukan membercheck agar dapat menunjukan bukti keabsahan data dengan meminta kebenaran data atau informasi secara langsung kepada masingmasing informan yang dimiliki.

\section{HASIL DAN PEMBAHASAN}

Kapital politik menjadi modal bagi seseorang untuk memiliki wewenang di antara orang lain dan menjelaskan simbol di atas hubungan sosialnya, sehingga dapat menunjukan kelas sosial pada seseorang yang sedang melakukan interaksi atau memiliki hubungan tertentu, seperti halnya hubungan kerja nelayan dengan pangamba'. Kapital politik yang identik dengan kelas dan wewenang, menempatkan pangamba' pada posisi yang lebih dominan atau tinggi, dengan didukung kepemilikan material dalam bentuk barang maupun uang (harta) yang tinggi tentu membawa pengaruh besar bagi kehidupan masyarakat pesisir khususnya nelayan. relasi kerja yang terjadi, menjadikan pangamba' seakan memiliki kekuasaan di atas hubungan kerja, meskipun sistim amba'an sudah mengatur kontrak kerja tersebut, kenyataannya nelayan memiliki kebiasaan setor hasil tangkap kepada pangamba', dan hal tersebut menjadikan kepatuhan tersendiri bagi nelayan kepada pangamba'.

Bagi Bourdieu (1986) dalam (Indrayani D. d., 2019), capital politic memiliki empat konsep dasar yaitu, (1) status sosial, yang berhubungan kelas sosial, stratifikasi sosial dan adanya wewenang yang berlaku untuk hubungan dua orang maupun terhadap adanya komunitas atau kelompok yang memiliki tujuan tertentu. (2) prestise sosial, dapat menunjukan sikap, tindakan atau perilaku seseorang ke arah gengsi dimana gengsi menunjukan kepeduliannya terhadap status. Meskipun begitu, prestise sosial juga menunjukan sikap hormat yang tinggi dan kewibawaan seseorang yang menyandang status sosial tertentu. (3) otoritas, lebih memperlihatkan bagaimana wewenang itu bekerja, sebab pada wewenang berhubungan langsung dengan kekuasaan yang dapat mempengaruhi orang lain dalam melakukan sesuatu. Dan (4) simbol sosial, berusaha memperlihatkan tanda atau gerak tubuh yang sedang menunjukan makna tersendiri dari apa yang sedang dilakukan oleh orang lain. Kapital politik, juga ditunjukan oleh masyarakat pesisir di Pondok Mimbo khusunya dalam hubungan kerja nelayan (pemilik kapal) dengan pangamba', meskipun kapital politik ditunjukan diluar hubungan kerja, namun hal tersebut sangat mempengaruhi ikatan kerja yang sudah disepakati, berikut penjelasanya: 


\section{Kuasa Pangamba'}

Wewenang dan kekuasaan terhadap hubungan kerja di alami oleh pangamba' sebagai investor terbesar untuk mencukupi kebutuhan kerja nelayan (pemilik kapal). Modal politik ini ditunjukan dengan cara penyerahan hasil tangkap nelayan yang harus diberikan kepada pangamba', dan keterikatan nelayan kepada pangamba' yang harus bekerja dengannya selama kontrak kerja dan harus mematuhi sistim amba'an yang telah disepakati. Terlepasnya nelayan dari pangamba' haruslah melunasi seluruh pinjaman modal dari pangamba', sehingga benar-benar terikat dengan kontrak kerja atas wewenang pangamba' itu sendiri terhadap nelayan.

Tempat pelelangan ikan (TPI) di Pondok Mimbo merupakan pusat aktivitas masyarakat pesisir di Pondok Mimbo, seperti pedagang, pemindang, belantik, pengecer, nelayan, bahkan pangamba' sepertihalnya Ibu MRN sebagai pangamba' tentunya akan selalu berjaga di tempat pelelangan ikan (TPI) untuk menunggu amba'annya mendarat untuk membawa hasil tangkap dan memberikannya untuk dijual, dan melakukan pembagian hasil. Seperti yang dikatakan Ibu MRN, berapapun hasil tangkap nelayan pasti akan di berikan kepada pangamba' karena hal tersebut adalah kesepakatan bersama di atas kontrak kerja. Sembari menjelaskan hal itu, Ibu MRN juga menambahkan bahwa, setelah di berikan kepada pangamba' masih memiliki tahapan yang lebih dalam melakukan transaksi jual dan beli, yaitu seperti pemindang, pedagang, dan dilakukan pengerasan ikan yaitu dibekukan untuk pengawetan.

\footnotetext{
'Iya, kan amba'annya orang sini itupun kalau dapet ikan. Cuma, kalau dapat sedikit ya dijual sendiri. Masak iya kalau pendapatan enggak balik modal, masih di ambil pangamba' kan keterlaluan namanya"

(Wawancara dengan informan Bapak AHN, 14 Desember 2019).
}

Nampaknya, meskipun nelayan itu dari luar Pondok Mimbo menjadikannya tetap harus memberikan hasil tangkapannya kepada pangamba' di Pondok Mimbo, hal tersebut karena segala bentuk hasil tangkap harus dijual melalui pangamba' yang menyebabkan nelayan luar tersebut harus memberikan hasil tangkapnya ke Pondok Mimbo dimana pangamba 'nya berada. Hal tersebut menunjukan kekuatan pangamba' terhadap kuasanya kepada nelayan atas kontrak kerjanya, disatu sisi pangamba' memang satu-satunya orang yang berani memberikan modal banyak kepada nelayan atau dapat dikatakan sebagai orang yang paling mampu di masyarakat pesisir Pondok Mimbo. Meskipun begitu, pada saat ini pangamba' sudah menjadi profesi pekerjaan di pesisir. Disampung itu, untuk berhenti berhubungan dengan pangamba', seorang nelayan (pemilik kapal) yang berhubungan dengan pangamba' harus membayar atau melunasi semua modal yang telah dipinjam. Enggak bayar adalah ketika hutang dari modal peminjaman nelayan dari pangamba' lunas atau sudah dibayar maka tidak ada pembayaran, setor hasil tangkap ataupun pembagian hasil antara nelayan dan pangamba', dalam artian lepas dari kontrak kerja.

Ketika berhenti terkadang belum tentu nelayan benar-benar lepas dari pangamba' atau tidak membutuhkannya. Seperti halnya yang dikatakan oleh Bapak BRT yaitu "pindah" dalam artian berpindah kerja dengan pangamba" lain ataupun berhenti haruslah melunasi hutangnya terlebih dahulu, sehingga nelayan nantinya dapat memutuskan untuk $a m b a$ ' sendiri atau lanjut berpindah dengan pangamba' lain. Kuasa pangamba' akan bekerja ketika ikatan itu terjadi, sepertihalnya kepatuhan dalam memberikan hasil tangkap ikan, dan dengan cara melunasi pinjaman modalnya maka, nelayan benar-benar terlepas dari kontrak kerja dengan pangamba'. Wewenang atau kuasa pangamba' yang begitu berhubungan dengan otoritasnya tidak akan berlaku jika seoarang nelayan (pemilik kapal) memutus ikatan kontrak kerja dengan melunasi modal pinjamannya.

\section{Persaingan Kerja Pangamba'}

Hubungan kerja antara nelayan dan pangamba', nampaknya bukan hanya memperlihatkan dari segi kebutuhan akan modal saja. Diluar hubungan kerja itu, nyatanya pangamba' seakan bersaing untuk mendapatkan amba'an atau seorang nelayan yang 138 | J S P H 
memumpuni atau kompeten, disatu sisi terkadang nelayan juga memiliki rasa kecewa ketika tidak diberi modal pinjaman tambahan oleh seorang pangamba' sehingga munculah tawaran lain dari pangamba' lain yang dapat menutupi kekurangan modal tersebut bahkan nelayan terkadang mencari amba'an baru untuk dapat menutupi kekurangannya yang tentu menguntungkan pangamba' baru itu sendiri.

Persaingan itu muncul karena sebab tertentu seperti ada masalah dalam hubungan kerja nelayan dan pangamba'. Ketika pangamba' tidak memberikan nelayan modal tambahan disaat dalam kondisi yang benar-benar membutuhkan, tentunya nelayan akan berusaha mencari pinjaman kepada orang lain. Pinjaman lain dapat didapatkan dari keluarga maupun tawaran dari pangamba' lain, sehingga jika pangamba' lain berani menawarkan lebih kepada nelayan maka keterikatan dengan pangamba' lama akan lepas dan berpindah ke pangamba' baru, sebab sudah terlunasi pinjamannya. Disatu sisi, nelayan memiliki modal tambahan, namun dengan hutang yang lebih dari pada sebelumnya, selebihnya pangamba' lama telah rugi karena sudah melepas asetnya dan memberikan keuntungan bagi pangamba' baru karena memiliki aset kerja tambahan. Persaingan pangamba' tidak dapat diterima oleh beberapa orang (nelayan) maupun dari pangamba' itu sendiri, sebab persaingan tersebut menjadikan konflik tersendiri bagi kedua belah pihak yaitu pangamba' karena saling berlomba untuk mendapatkan nelayan yang memumpuni sehingga nantinya dapat menguntungkan pemasukan dari pangamba' itu sendiri, berikut penjelasanya:

"Ya kalau persaingan kerja itu pasti ada dek pangamba'. Kalau nelayan itu ya tergantung rezekinya sudah. Kalau pangamba' contohnya kayak Ibu PJ sama Ibu MRN. Jadi waktu itu, Ibu PJ punya nelayan dek, terus enggak tahu kenapa mau diambil sama MRN. Bisa jadi karena MRN lebih besar modalnya, dan pada saat itu sampai bertengkar itu dek, ya gimana lagi kalau amba'anya diambil langsung kan ya pasti marah, tentunya ya rugi ke penghasilan itu nanti"

(Wawancara dengan informan Ibu SS, 22 Desember 2019).
Persaingan kerja pangamba' di atas menunjukan adanya konflik karena terdapat salah satu pihak yang mengambil aset atau nelayan dari pangamba'nya sendiri. Konflik tersebut terjadi karena tidak adanya musyawarah yang jelas di atas kontrak kerja tanpa persetujuan dari pangamba'. Sehingga nantinya menyebabkan kondisi emosional yang tinggi, disatu sisi modal yang lebih besar tentu menjadi keuntungan tersendiri bagi nelayan, sehingga memberikan peluang besar untuk mencukupi kebutuhan kerjanya. Namun, dalam diluar itu berdampak pada pangamba' itu sendiri yang sudah berisiko menanam suatu persaingan ketat terhadap pangamba' lain, sebab nelayan merupakan satu-satunya aset atau rekan kerja yang nantinya dapat memberikan pemasukan bagi pangamba'. Sehingga tidak salah, jika nelayan menjadi orang yang paling direbutkan, terlebih lagi jika nelayan tersebut berkualitas dari segi kapal, alat tangkap, bahkan untuk jumlah ABK yang memumpuni. Disatu sisi, salah satu nelayan juga mendapat tawaran lebih besar dari pangamba' lain namun, tidak diterima karena sudah memiliki kepercayaan lebih terhadap seorang pangamba'nya, berikut ungkapnya:

"Pernah dulu itu, kalau saya mau kerja sama dia, Rp. 100.000.000,00 berani katanya langsung dikasih. Tapi ya gimana, saya enggak mau nak. Soalnya, enggak enak sama H. Namisah, sudah berbuat banyak ke saya, lagian saya juga tidak ada masalah denganya, orangnya juga baik sampai saat ini"'

(Wawancara dengan informan Bapak BRT, 13 Februari 2020).

Persaingan kerja nyatanya menunjukan adanya prestise sosial di antara pangamba'. Sebab, di dalam persaingan kerja tentu tidak akan ada yang akan mengalah untuk mempertahankan suatu aset kerjanya yaitu nelayan. Disatu sisi, prestise tersendiri menunjukan adanya gengsi yang dimiliki oleh beberapa dari para pangamba' untuk mempertahankan kewibawaannya masingmasing. Mereka yang menunjukan dengan cara berlomba untuk memberikan modal yang lebih besar dari pangamba' yang lain, sehingga memicu untuk memberikan modal besar secara 
terus menerus. Seperti halnya, Bapak BRT yang menerima tawaran lebih dari pangamba' lain tentu menunjukan persaingan yang membawa pada sebuah gengsi tersendiri terhadap pangamba' dari Bapak BRT yang tentu beranggapan dapat memberinya modal lebih besar dari pada sebelumnya. Hal tersebut juga menunjukan, seakan pangamba' tersebut lebih mampu dan memperlihatkan kewibawaan yang lebih terhadap nelayan, namun sebaliknya karena modal yang besar belum tentu menjamin seorang nelayan dapat bergabung untuk bekerja sama dengan pangamba', sebab jujur dan baik dalam menjaga kepercayaan suatu hubungan kerja.

\section{Tindakan Kecurangan dalam Kontrak Kerja}

Kecurangan tersebut diciptakan oleh nelayan dan pangamba' dalam hubungan kerja mereka sendiri. Perilaku tersebut tentunya dilakukan untuk mendapatkan suatu penghasilan yang lebih, sehingga penghasilan lebih tersebut dapat dijadikan sebagai modal kerja tambahan, berikut penjelasanya:

1. Kecurangan Pangamba'

Pangamba' menjadi sosok yang paling dibutuhkan nelayan guna mencukupi kebutuhan kerja mereka. Namun, beberapa di antaranya justru memanfaatkan untuk mendapatkan penghasilan lebih. Sebagai pangamba' tentunya memiliki kekuasaan lebih atas kontrak kerja tersebut sehingga, melakukan kecurangan dalam bentuk pemotongan harga ikan secara diamdiam meskipun terkadang diketahui oleh nelayan, namun tidak memiliki kuasa penuh.

Tindakan yang dilakukan oleh seorang pangamba' tersebut dalam melakukan kecurangan ialah dengan cara bekerja sama dengan seorang pedagang ataupun belantik pada saat melakukan jual beli ikan yang didapatkan oleh nelayan. Pemotongan harga ikan tentunya akan dapat mempengaruhi pembagian hasil, sebab potongan harga seribu saja dapat mempengaruhi pendapatan nelayan. Potongan persenan dari kontrak kerja tentu akan berdampak pada nelayan, setiap potongan memberi keuntungan bagi pangamba' dan berkurangnya hasil dari nelayan, karena menyebabkan potongan dua kali lipat dan hal tersebut sangat merugikan dan memberi keuntungan yang berat sebelah. Sebab, pangamba' nantinya dapat menjual harga yang memiliki nominal satu tingkat lebih tinggi, ditambah lagi potongan harga ikan dari hasi penjualan diluar kesepakatan yaitu Rp. 2000,00 pastinya memiliki keuntungan yang berlipat ganda. Selebihnya, dijelaskan oleh informan lain yaitu kecurangan tersebut ditunjukan dengan memberikan isyarat ataupun tindakan dari gerakan tubuh sebagai simbol untuk memberikan petunjuk bagi orang lain.

Nyatanya, dalam melakukan tindakan curang dalam mendapatkan keuntungan lebih dalam hubungan kerjanya. Pangamba' melakukannya dengan cara memberikan isyarat tertentu seperti yang dikatakan oleh Ibu SS "tinggalin saya seribu" dengan maksud memberikan suatu petunjuk bagi pedagang ataupun seorang belantik agar memberikan harga yang murah sehingga menjadikan pangamba' akan mendapatkan keuntungan Rp. 2000,00 per kilogramnya. Selebihnya, simbol lain ditunjukan dengan gerak tubuh seperti "menampol paha" berusaha memberikan suatu petunjuk bagi penimbang, pedagang, maupun belantik agar memberikan harga yang murah juga. Beberapa simbol juga ditunjukan oleh pangamba' guna memperoleh keuntungan yang lebih dengan memanfaatkan hasil tangkap nelayan. Hal ini juga menunjukan, bahwa dalam kapital politik menunjukan adanya bentuk simbol yang berperan dalam memberikan isyarat kepada orang lain untuk mencapai tujuan terhadap kepentingan dan keutungannya sendiri.

2. Kecurangan Nelayan

Kecurangan bukan hanya terfokus pada beberapa pangamba', namun beberapa nelayan juga melakukan tindakan kecurangan untuk mendapatkan keuntungan yang lebih. Beberapa informan menjelaskan, bahwa kecurangan beberapa nelayan yang dilakukan dengan cara menyembunyikan ikan agar tidak diketahui oleh pangamba', hal tersebut dilakukan agar nelayan nantinya mendapat keuntungan yang utuh. Utuh dalam artian adalah tidak terkena potongan persenan dari kesepakatan kontrak kerja atau sesuai sistim amba'an yang berlaku yaitu $10 \%$ 
hingga $20 \%$ pemotongan harga dari hasil tangkap ikan, berikut penjelasanya:

"Terkadang nelayan juga enggak jujur dek, caranya nelayan itu kalau dapat ikan enggak langsung dibawa ke TPI, tapi dibawa langsung ke rumahnya. Misal dapat 1 kuintal ikannya ditaruh didalam satu blung, itu nanti ikannya ditaruh ke ember misal ada sepeuluh ember ya ditaruh kedalam sepuluh ember ikan 1 kuintal itu tadi, biar enggak ketahuan pangamba'. Biar apa ? biar tidak kena potongan pangamba' dek, jadi hasilnya bisa utuh bagi nelayan"

(Wawancara dengan informan Bapak SND, 22 Desember 2019).

Sebagai seorang nelayan dan sekaligus pemilik kapal maupun nahkoda, Bapak SND tentunya mengetahui kecurangan beberapa nelayan yang sudah diketahui. Tindakan yang dilakukan ditunjukan dengan cara menyembunyikan ikannya kedalam blung atau ember, sehingga pangamba' tidak mengetahui jika amba'annya mendapatkan hasil tangkap ikan. Disatu sisi, nelayan dapat memiliki keuntungan yang utuh dari penjualan hasil tangkapnya, tentunya tanpa melewati pemotongan persenan atau bagi hasil dengan pangamba' sehingga pendapatan nelayan benarbenar utuh. Namun, resiko dari tindakan tersebut dapat menyebabkan putusnya kontrak kerja dari pangamba' karena keuntungan yang bersepihak dan tentu merugikan pangamba' itu sendiri, disatu sisi tindakan tersebut menyalahi kesepakatan kerja atau norma yang berlaku dalam melakukan relasi kerja itu sendiri.

\section{Pengaruh Persaingan Pedagang}

Pedagang menjadi salah satu individu yang dapat membantu dalam proses pembelian terhadap hasil tangkap nelayan. Tentunya, para nelayan yang memiliki pangamba' yang harus melewati perantara pangamba' untuk dapat menjualkan hasil tangkapnya, hingga begitu nelayan dapat memiliki pendapatan dari hasil penjualan ikannya. Namun, terdapat lika-liku tertentu antara pedagang luar dan pedagang dalam di Pondok Mimbo, yaitu seakan pedagang luar tidak dapat untuk memasuki area tempat pelelangan ikan di Pondok Mimbo. Menurut beberapa informan, sebenarnya pedagang luar boleh diperkenankan masuk namun, ada permasalahan yang membuat pedagang luar tidak dapat memasuki area tersebut hingga sekarang yaitu diantaranya seperti terdapat konflik antara pedagang sehingga menyebabkan perkelahian dan disatu sisi pedagang Mimbo akan selalu berusaha untuk menghadang pedagang luar untuk memasuki area tempat pelelangan ikan (TPI).

Alasan pedagang dari luar Pondok Mimbo tidak diperkenankan masuk yang pertama adalah berupa terjadinya konflik yang di alami oleh pemindang Pondok Mimbo yang mendapat kekerasan dari pedagang, sehingga nantinya kejadian tersebut mengakibatkan sulitnya akses pedagang luar untuk memasuki wilayah tempat pelelangan ikan (TPI) di Pondok Mimbo. Kemudian, dari Bapak AHN menunjukan hal lain yaitu bahwa pedagang luar sering dihadang agar tidak memasuki area tempat pelelangan ikan (TPI) di Pondok Mimbo.

Pedagang luar tidak masuk karena dihadang oleh beberapa pelaku pemasaran di Pondok Mimbo yaitu pedagang maupun belantik yang berada di Pondok Mimbo, yang berusaha menghentikan pedagang luar agar tidak memasuki area tempat pelelangan ikan (TPI). Selain itu, pedagang luar dikenal sebagai seseorang yang dapat membeli ikan dengan jumlah yang tinggi, sehingga mengalahkan nilai beli dari pedagang Pondok Mimbo itu sendiri.

"Iya memang enggak boleh masuk, tapi boleh masuk kalau bayar komisi dek. Komisinya itu bisa 500, misal ada ikan harganya 10 ribu. $\mathrm{Nah}$, pedagang luar itu harus bayar ke saudagar sini itu Rp. 10.500 yang 500 nya itu untuk saudagarnya. Saudagar itu bisa pedagang atau belantik Mimbo sini. Untuk bayarnya kadang itukan tidak langsung tunai dek, jadi saudagar sini yang harus bisa tanggungjawab untuk bayar ikannya ke nelayan. Ya kan tidak mungkin ikan berton ton bisa dibayar sekaligus, ya harus dijual dulu. Setidaknya pedagang luar itu bisa bayar 2 sampai 3 hari dek, baru saudagar di Mimbo bisa balik modalnya"

(Wawancara dengan informan Bapak SND, 22 Desember 2019).

Penjelasan komisi diperjelas oleh Bapak SND, bahwa komisi tersebut dikenakan biaya sebesar Rp. 500,00 per kgnya. Disatu sisi, pembayaran yang diberikan tidak secara 
langsung dari pedagang luar ke pedagang dalam. Sehingga, saudagar Pondok Mimbo harus membayar terlebih dahulu kepada pangamba' sebagai hasil penjualannya. Jikapun tidak, saudagar Pondok Mimbo harus menunggu saudagar luar untuk membayarnya paling tidak dalam jangka waktu 2-3 hari baru dapat menerima pembayaran, yang tentu juga akan dilangsungkan kepada pangamba', disatu sisi pangamba' sudah membayar upah atau hasil nelayan sehingga untung atau balik modalnya pangamba' memang harus menunggu dari hasil saudagar itu sendiri. Mengingat, pedagang luar nyatanya sangat diharapkan oleh nelayan Pondok Mimbo karena memiliki jual ikan yang tinggi, sehingga nantinya dapat memberikan keuntungan lebih bagi nelayan dan pangamba'. Namun, karena permasalahan tersebut yaitu terhadangnya akses masuk pedagang luar, beberapa nelayan berharap bahwa pedagang luar agar diperkenankan masuk. Namun, otoritas atau kekuasaan dari pedagang sangatlah kuat sehingga, nelayan memiliki kesulitan dalam melawan hal tersebut.

Alasan nelayan tidak dapat melakukan upaya agar pedagang luar dapat masuk kedalam Pondok Mimbo, karena para nelayan kurang menguasai permasalahan politik untuk menangani kasus seperti itu. Hal yang di inginkan nelayan adalah memiliki penghasilan yang lebih, namun hal tersebut bertolak belakang dengan harga jual ikan yang rendah hingga sedang di Pondok Mimbo sehingga satusatunya jalan adalah membiarkan pedagang luar masuk agar nelayan dapat menjual harga ikan dengan harga tinggi atau normal di atasnya. Saat ini, wewenang dan otoritas pasar seakan dipegang oleh saudagar Pondok Mimbo yaitu pedagang dan belantik itu sendiri. Disatu sisi, nelayan berharap ada satu sosok yang paham akan politik dan dapat mengatasi kondisi seperti ini, yang nantinya dapat menjadikan pedagang luar dapat masuk. Sehingga, nelayan dapat memiliki pendapatan yang lebih dan kondisi ekonomi tentunya lambat laun akan terus membaik, selebihnya pangamba' tentu akan menerima hasil yang lebih juga dari hasil kerja sama atau kontrak kerja dengan nelayan.

\section{PENUTUP}

Kuasa pangamba' terhadap nelayan atas relasi kerjanya bukan semata hanya untuk menunjukan tentang kuasa dan wewenangnya, namun dalam masyarakat pesisir pada seorang pangamba' dapat dikategorikan berada dalam status sosial yang tinggi. Kelas sosial yang tinggi, pada masyarakat pesisir ditunjukan dengan menggunakan simbol atau benda seperti rumah, kapal, dan tingkat ekonomi keluarga yang tinggi menunjukan bahwa pangamba' merupakan orang yang memiliki ekonomi yang tinggi pula, disatu sisi pangamba' menjadi satusatunya orang yang berani menanamkan modal tinggi kepada nelayan.

Selebihnya, peran dari kapital politik menunjukan adanya persaingan antara pedagang dalam dan pedagang luar Pondok Mimbo. Hal tersebut menunjukan adanya otoritas dari kuasa dan wewenang yang diberikan pedagang dalam kepada pedagang luar agar tidak memiliki akses ke Pondok Mimbo, sehingga menjadikan pedagang dalam untuk berkuasa dalam pasar lokal terutama untuk aktivitas jual beli yang dilakukan nelayan dan pangamba' kepada pedagang dalam di Pondok Mimbo. Pengaruhnya dari kuasa pedagang dalam terhadap adanya relasi nelayan dan pangamba', menjadikan nelayan tidak dapat menjualkan ikannya kepada pedagang luar yang dapat membeli dengan harga mahal, disatu sisi nelayan dan pangamba' mengharapkan suatu hal tersebut. Meskipun pedagang luar memiliki akses dan mendapat komisi, mereka hanya dapat membeli ikan dari hasil tangkap nelayan melalui perantara dari pedagang dalam dan juga bersedia membayar komisi pada setiap kilogramnya.

Alhasil, dalam peran kapital politik menunjukan keberadaan dan posisinya dalam memperlihatkan bentuk dari kuasa yang dimiliki pada setiap orang khususnya nelayan dan pangamba'. Kuasa yang diberikan juga memiliki maksut tertentu demi mendapatkan suatu keuntungan. Sehingga, kuasa yang terjadi dalam relasi kerja nelayan dan pangamba' begitu mengikat yang didukung dengan kepatuhan nelayan terhadap pangamba'. Disatu sisi, norma lain juga mengikat dan didukung 
dengan adanya pemegang kuasa seperti halnya pedagang dalam Pondok Mimbo yang memiliki kuasa, yang mempengaruhi relasi nelayan dan pangamba'.

Batas penelitian ini berfokus pada bentuk relasi yang di implimentasikan dalam bentuk kapital politik, sehingga penelitian ini dapat menguak hubungan politik yang terjadi antara nelayan dan pangamba'. Sebagai bentuk rekomendasi, perlu adanya solusi dalam menindak lanjuti bentuk kecurangan yang terjadi dalam hubungan kerja nelayan dan pangamba', sehingga hubungan kerja tersebut dapat terjalin dengan sehat dan maksimal, dengan adanya hal tersebut tentu akan menguntungkan kedua belah pihak, entah dari segi materi maupun sosial.

\section{DAFTAR RUJUKAN}

Damsar \& Indrayani. (2019). Pengantar Sosiologi Kapital. Jakarta Timur: Prenadamedia Group.

Erfan, J. (2014). Peran Pangamba' sebagai Lembaga Keuangan Informal dalam Sistem Perikanan Tangkap. Skripsi. Malang: Universitas Muhammadiyah Malang.

Indriadewi Atmadjaja, Y. (2017). Identifikasi Keberadaan Pengamba' Dan Pola Relasi Dengan Masyarakat Nelayan Pesisir Timur Banyuwangi. Ekspektra : Jurnal Bisnis Dan Manajemen, 1(1), 31-45.

DOI:http://dx.doi.org/10.25139/ekt.v1i 1.86

Kumalasari, B., Herawati, T., \& Simanjuntak, M. (2018). Relasi Gender, Tekanan Ekonomi, Manajemen Keuangan, Strategi Nafkah, dan Kualitas Hidup pada Keluarga Nelayan. Jurnal Ilmu Keluarga \& Konsumen, 11(2), 108119.

DOI:https://doi.org/10.24156/jikk.201

8.11.2.108

Kusnadi. (2009). Keberdayaan Nelayan dan Dinamika Ekonomi Pesisir. AR-RUZZ MEDIA: Jogjakarta.
Kusnadi. (2001). Pangamba' Kaum Perempuan Fenomenal. Humaniora Utama Press: Bandung

Muhartono, R. dan Nurlaili. (2018). Hutang Sebagai Pengikat Hubungan Nelayan dan Pengambe'. Jurnal Sosek, Vol. 13 No. 2. Jakarta Utara: Balai Besar Riset Sosial Ekonomi Kelautan dan Perikanan.

Moita, S. (2017). Kearifan Lokal Masyarakat Etnis Tolaki Dalam Pengelolaan Sumber Daya Pesisir Di Kecamatan Lalonggasumeeto Kabupaten Konawe Provinsi Sultra. Jurnal Sosiologi Pendidikan Humanis, 2(1), 16-22. Retrieved

From http://journal2.um.ac.id/Index.ph $\mathrm{p} / \mathrm{jsph} /$ article/view/2404

Retnowati, E. (2011). Nelayan Indonesia Dalam Pusaran Kemiskinan Struktural (Perspektif Sosial, Ekonomi Dan Hukum). Perspektif, 16(3), 149-159. DOI:http://dx.doi.org/10.30742/perspe ktif.v16i3.79

Soekanto, S. (2013). Sosiologi Suatu Pengantar. Jakarta: Raja Grafindo Persada.

Sugiyono. (2018). Metode Penelitian Kuantitatif, Kualitatif, dan R\&D. Bandung: Alfabeta.

Syafrini, D. (2014). Nelayan Vs Rentenir. Jurnal Mamangan, Vol. 1 No. 2. Sumbar: STKIP PGRI Sumbar.

Yasir, M. (2017). Keadaan Sosial Ekonomi Nelayan Bagan. Skripsi. Bandar Lampung: Universitas Lampung.

Yovita, V. I. A. (2017). Identifikasi Keberdayaan Pangamba' dan Pola Relasi dengan Masyarakat Nelayan Pesisir Timur Banyuwangi. Jurnal Manajemen dan Bisnis, Vol. 1 No. 1 Hal : 31-45. Banyuwangi : Universitas 17 Agustus 1945 